\title{
GYDYTOJO ASMENYBE் IR GYNYBINĖS MEDICINOS PRIEMONIŲ NAUDOJIMAS
}

\author{
Viktoras Justickis \\ Mykolo Romerio universiteto Socialinių technologijų fakulteto \\ Psichologijos institutas \\ Ateities g. 20, LT-08303 Vilnius, Lietuva \\ Telefonas (+370 6) 1533289 \\ Elektroninis paštas justickv@takas.lt

\section{Rita Bandzevičienè} \\ Mykolo Romerio universiteto Socialinių technologijų fakulteto \\ Psichologijos institutas \\ Ateities g. 20, LT-08303 Vilnius, Lietuva \\ Telefonas (+370 6) 1423196 \\ Elektroninis paštas rbandze@mruni.eu

\section{Laimutis Paškevičius} \\ Mykolo Romerio universiteto \\ Politikos ir vadybos fakulteto Politikos mokslų institutas \\ Valakampių g. 5, LT-10101 Vilnius, Lietuva \\ Telefonas (+370 6) 9849757 \\ Elektroninis paštas laimutis.paskevicius@medcentras.lt
}

\section{Ina Božokienè}

Vši Respublikinė Kauno ligoninè

Hipodromo g. 13, Vilnius, Lietuva

Telefonas (+370 6) 5769507

Elektroninis paštas inabozokiene@gmail.com

Pateikta 2014 m. rugpjūčio 20 d., parengta spausdinti 2014 m. spalio 1 d.

$$
\text { doi:10.13165/SPV-14-2-7-10 }
$$

\section{Santrauka}

Gynybinè medicina - tai ydingas sveikatos apsaugos reiškinys, kai gydytojas, užuot daręs viska paciento sveikatai pagerinti, siekia užtikrinti savo paties sauguma nuo galimo teisinio persekiojimo sveikatos priežiūros (medicinos, odonto- 
logijos, kt.) paslaugu teikimo nesékmès atveju. Lietuvoje atlikti tyrimai parodé dideli šio neigiamo reiškinio paplitima, jo neigiama poveikị sveikatos paslaugoms (Labanauskas, Justickis, 2011). Buvo nustatyti ši reiškini sukeliantys veiksniai. Išryškejje gydytoju atsparumo ar, atvirkščiai, jautrumo šiu veiksniu įtakai individualūs skirtumai (Labanauskas, Justickis, 2013) ir paskatino nauja tyrima, kurio tikslas - nustatyti polinkio naudoti gynybinès medicinos priemones sasajas su gydytojo asmenybès ypatumais. Tyrime dalyvavo 101 Kauno m. ligoniniu gydytojas. Tyrimas atliktas naudojant klausimyna, kurị sudare asmenybès bruožu įvertinimo metodika NEO-PI-R (Costa and McCrae, 1992) (lietuviškoji versija) ir speciali Gynybinès medicinos taikymo anketa (GMTA), skirta įvertinti gydytojo polinkiui naudoti gynybines medicinos priemones.

Tyrimo rezultatai parode glaudu ryšç tarp gydytojo asmenybès ir jo polinkio naudoti gynybinès medicinos priemones, taip pat ryškų monofaktorini šio ryšio pobūdį. Nustatyti gydytojo asmenybès ypatumai, kurie labiausiai prisideda prie gydytojo polinkio naudoti gynybinès medicinos priemones, šio polinkio sasajos su pamatiniais asmenybès bruožais.

Asmenybès bruožu, kurie padidina gydytojo jautruma gynybinès medicinos veiksniu poveikiui, nustatymas leido išskirti kontingenta gydytojų, kuriems labiausiai reikalinga organizacinè ir psichologiné pagalba ju atsparumui minètiems veiksniams padidinti. Aptartos psichologiniu priemoniu (ypač Balinto grupiu) panaudojimo perspektyvos, siekiant padeti gydytojams ivveikti gynybine medicina ir nepageidaujamas jos pasekmes, užtikrinant kompleksini požiūrį i ju prevencija ir pacientų sauga (Paškevičius, 2014).

Reikšminiai žodžiai: gydytojo asmenybè, gynybinè medicina, nepageidaujami atvejai, gydytojo atsakomybe, Balinto grupes.

\section{İvadas}

\section{Problema}

Gynybinè medicina - tai ydingas sveikatos apsaugos reiškinys, kai gydytojas užuot daręs viską paciento sveikatai pagerinti, siekia užtikrinti savo paties apsisaugojimą nuo galimo teisinio persekiojimo gydymo nesėkmės atveju ${ }^{1}$. Svarbiausia gynybinès medicinos priežastis yra ydinga gydytojo teisinès atsakomybės už gydymo rezultatus sistema, kai reikalavimai gydytojui nustatomi pažeidžiant įvykdomumo principą ${ }^{2}$.

Tokia atsakomybės sistema skatina gydytojus imtis gynybos nuo galimo persekiojimo veiksmų, kurie gali būti: sunkių ir sudètingų atvejų vengimas, delsi-

Labanauskas, L.; Justickis, V.; Sivakovaitè, A. İstatymo ịvykdomumas. Šiuolaikinè gydytojo atsakomybès didinimo tendencija. Socialiniu mokslu studijos. 2010, 4(8): 89-107.

$2 \quad$ Ibid., p. 89. 
mas ar iš viso vengimas priimti atsakingus diagnostinius ir gydymo sprendimus, nebūtinų vaistų skyrimas, nereikalingi siuntimai konsultuotis pas kitus gydytojus specialistus ir pan.

2011 m. reprezentatyvus 2440 Lietuvos gydytojų tyrimas, kuri kartu atlikto MRU ir Lietuvos gydytojų sąjunga, parodè didelị gynybinès medicinos reiškinių paplitimą Lietuvoje. Nustatyta, kad net 86,3 proc. gydytojų siunčia pacientą pas kitus gydytojus specialistus ne dèl to, kad to tikrai reikia (būtų patikslinta diagnozė ar gautas naudingas patarimas skiriant ar tikslinant gydymą), bet tik tam, kad apsisaugotų nuo galimo teisinio persekiojimo; 60,7 proc. gydytojų tais pačiais sumetimais skiria nereikalingus papildomus tyrimus; 66,6 proc. vengia rizikingų pacientų, t. y. sergančių sudètinga ar pavojinga liga, taip pat žinančių ir siekiančių ginti savo teises; 59,9 proc. vengia atlikti reikalingas, bet rizikingas procedūras; 40,3 proc. išrašo nereikalingus vaistus, nes pacientas to reikalauja darydamas gydytojui spaudimą ${ }^{3}$.

Tokie reiškiniai daro neigiamą poveiki gydytojo teikiamų paslaugų kokybei ir visai Lietuvos sveikatos priežiūros sistemai. Dẻl gynybinės medicinos reiškinių tūkstančiai papildomų pacientų eilèse laukia vien tam, kad juos siuntęs gydytojas galètų formaliai apsiginti nuo galimų teisinių ir kitokių priekaištų. Dèl šio reiškinio labiausiai nukenčia tie pacientai, kuriems konsultacija ar tyrimas yra iš tikrųjų būtinas. Dẻl gynybinės medicinos ypač nukenčia sunkiomis ligomis sergantieji bei pacientai, kurių diagnozè neaiški. Jie negauna reikiamų sveikatos priežiūros paslaugų vien dèl to, kad jų atveju reikia priimti drąsius, ryžtingus, dažnai ir rizikingus sprendimus. Gynybinė medicina sukelia dar vieną reiškinị vaistų skyrimą paciento reikalavimu. Daugybė pacientų perka ir vartoja nebūtinus vaistus, tam be reikalo eikvodami savo lèšas. Bereikalingas vaistų (ypač antibiotikų) skyrimas mažina gydymo veiksmingumą, sukelia nepageidaujamą poveiki.

Minèti tyrimai ne tik leido nustatyti bendruosius veiksnius, kurie skatina gynybinès medicinos metodų taikymą, bet ir išryškino individualius skirtumus tarp atskirų gydytojų atsparumo ar, atvirkščiai, jautrumo gynybinès medicinos veiksniams (Labanauskas, Justickis, 2013) ${ }^{4}$.

Paaiškejjo, kad šis individualus jautrumas paaiškina 31,6 proc. polinkio taikyti gynybos priemones skirtumus tarp gydytojų ${ }^{5}$.

Atskleisti faktai skatina ieškoti atsakymo ị tolesnị klausimą: iš kur atsiranda individualūs gydytojų jautrumo skirtumai, kokie individualūs gydytojo asme-

Labanauskas, L.; Justickis, V.; Sivakovaitė, A.Gynybinès medicinos reiškinių paplitimas Lietuvoje (Pagrindiniai 2440 Lietuvos gydytojų tyrimo rezultatai). Sveikatos politika ir valdymas. 2011, 1(3): $158-170$.

4 Labanauskas L.; Justickis, V.; Sivakovaitė, A. Gynybinė medicina Lietuvos sveikatos apsaugoje: gydytojų gynybinių reakcijų formavimasis. Sveikatos politika ir valdymas. 2013, 1(5): 134-147.

Ibid., p. 139 
nybės ypatumai juos nulemia? Kurie atskiro gydytojo asmenybės ypatumai padidina jo jautrumą gynybinès medicinos veiksniams, o kurie, atvirkščiai, didina jo atsparumą jiems?

Asmenybės bruožų, kurie padidina gydytojo jautrumą gynybinès medicinos veiksnių poveikiui, atskleidimas leistų patikslinti jautriausių gynybinès medicinos veiksniams gydytojų kontingentą, nustatyti jiems reikalingą organizacinę ir psichologinę pagalbą, rasti priemones jų atsparumui minètiems veiksniams padidinti. Kartu atsiveria naujos perspektyvos numatyti gynybinès medicinos sukeliamus nepageidaujamus atvejus gydytojo veikloje, užtikrinant kompleksini jų valdymą

\section{Tyrimo mokslinis naujumas}

Gynybinès medicinos reiškiniai sulaukè didelio tyrèjų dèmesio ${ }^{7}$. Aiškinant šio reiškinio priežastis, nurodomos, visų pirma, bendrosios sveikatos apsaugos organizavimo ir kitos problemos, kurios apsunkina gydytojo darbą ir skatina ji panaudoti gynybinès medicinos priemones, pavyzdžiui, išaugęs gydytojo darbo krūvis dèl padidejjusio pacientų srauto, nepakankamas laiko skyrimas pacientui dèl padidejusio užimtumo, gydytojo nuovargis ir kt.

Tačiau kol kas tyrinèti tik bendrieji (organizaciniai, ekonominiai, teisiniai) veiksniai, kurie visuomenès mastu sukelia gynybinès medicinos reiškinius, bet visai netirti individualūs, psichologiniai veiksniai, kurie daro įtaką atskiro gydytojo elgsenai ir paaiškina gydytojų jautrumo ar atsparumo minètiems gynybinès medicinos veiksniams skirtumus. Šis tyrimas yra pirmas bandymas atskleisti sąsajas tarp gydytojo asmenybės ypatumų ir jo polinkio naudoti gynybinès medicinos priemones.

\section{Mokslinè ir praktiné reikšmé}

Tyrimas praplečia gynybinès medicinos reiškinių supratimą, atskleidžia naujus veiksnius, kurie ženkliai prisideda prie šių nepageidaujamų reiškinių paplitimo. Tyrimo rezultatai leidžia atskleisti „žmogiškosios“, subjektyvios reiškinio pusės supratimą, atkreipia dėmesị ị gydytojo asmenybės reikšmę gynybinių reakcijų formavimuisi ir jų prevencijai.

Praktiniu požiūriu tyrimas svarbus, nes pateikia naudingų ižzvalgų tobulinant nepageidaujamų atveju gydytojo veikloje numatymą, diegiant naujas jų prevencijos priemones. Kaip minèta, gydytojo polinkis vengti rizikingų sprendimų sukelia tokius nepageidaujamus reiškinius kaip pavèluota diagnozé, gydymui svarbių gydymo priemonių nepanaudojimas, apskritai ne visų pagalbos pacien-

Paškevičius, L. Kompleksinio požiūrio ị pacientų saugą ir rizikos valdymą sveikatos priežiūros organizacijose paieška. Sveikatos politika ir valdymas. 2014, 1(6): 133-156.

7 Labanauskas, L.; Justickis, V.; Sivakovaitè, A. İstatymo ịvykdomumas. Šiuolaikinė gydytojo Atsakomybès didinimo tendencija. Socialiniu mokslu studijos. 2010, 4(8): 89-107. 
tui galimybių išnaudojimas. Todẻl tyrimas, kuriame išryškinami veiksniai, susiję su didesniu gydytojo atsparumu gynybinès medicinos poveikiui, padeda numatyti ir naujas šių nepageidaujamų reiškinių rizikos bei kontrolès priemones.

\section{Straipsnio struktūra}

Straipsnis sudarytas iš ịvado, kuriame pristatoma problema, trijų skyrių ir išvadų. Pirmajame skyriuje apžvelgiama tyrimo organizavimas ir metodai, antrajame išdesstyti ir aptarti tyrimo rezultatai. Trečiajame skyriuje formuluojamos išvados ir nurodomos praktinés priemonès, kurias diktuoja tyrimo rezultatai.

\section{Tyrimo organizavimas ir metodai}

Tyrimo objektas - gydytojo asmenybės bruožai ir polinkis naudoti gynybinès medicinos priemones.

\subsection{Gydytojų pamatinių asmenybės bruožų tyrimo metodika}

Gydytojo asmenybės ypatumams tirti buvo naudota asmenybès bruožu įvertinimo metodika NEO-PI-R (Costa and McCrae, 1992), jos lietuviškoji versija, pasižyminti ypač gerais psichometriniais rodikliai ${ }^{8}$. Pamatinių asmenybès bruožų tyrimo teorinis pagrindas - Penkių faktorių modelis (PFM; angl. Five-Factor Model, FFM.), kitaip dar vadinamas „Penketu svarbiausiųjų“ (angl. Big Five), kuris penkias asmenybės bruožų dimensijas - neurotizmą, ekstraversiją, atvirumą patyrimui, sutariamumą ir sąmoningumą - sujungia ị bendrą asmenybės struktūrą aprašančią schemą (McCrae and John, 1992; McCrae and Costa, 1997).

Ši metodika užima ypatingą vietą psichologijos istorijoje ir dabartiniuose asmenybės tyrimuose. Nors per ilgą psichologijos istoriją sukurta daugybė psichologinių asmenybės bruožų tyrimo metodikų, visos jos buvo tik siauros paskirties, skirtos tirti atskirus žmogaus asmenybės bruožus ir tų bruožų pasireiškimą atskirose, neretai gana specifinėse situacijose ${ }^{9}$. Tačiau nemažai psichologų siekè realizuoti ambicingą sumanymą - parengti universalią asmenybės tyrimo metodiką. Tam tikslui, visų pirma, reikèjo nustatyti pamatinius asmenybės bruožus, tai yra tokius, nuo kurių priklauso visi kiti asmens bruožai ir kurie leistų numatyti asmens reakcijas pačiose įvairiausiose situacijose.

Dar 1884 metais garsus britų psichologas Francis Galtonas iškèlè idèją, kad tokios universalios metodikos pagrindas turètų būti labai platus asmenybès

8 Žukauskienè, R.; Barkauskienè, R. Lietuviškosios NEO PI-R versijos psichometriniai rodikliai. Psichologija. 2006, 33: 7-21.

$9 \quad$ Kaplan, R.; Saccuzzo, D. Psychological Testing: Principles, Applications, and Issues Dennis Cengage Learning, Psychology, 2008. 
charakteristikų sąrašas, kurio apibendrinimas ir leistų išskirti pamatinius asmenybės bruožus ${ }^{10} .1936$ metais JAV psichologai G. Allportas ir S. Odbertas sukūrè tokị asmenybès charakteristikų sąrašą, kuris apemė 4,504 asmenybès bruožus ${ }^{11}$. Šiuo pagrindu buvo sukurta keletas universalių asmenybės tyrimo metodikų (testų) $)^{12}$. Jos sukèlè didelị susidomejjimą ir buvo plačiai taikomos. Tačiau jų patikimumas nebuvo toks, kad jomis būtų galima pakankamai tiksliai prognozuoti ịvairias asmenybės reakcijas ịvairiose situacijose.

Situacija pasikeitè praeito amžiaus aštuntame dešimtmetyje, kai net keturios tyrèjų grupès nepriklausomai viena nuo kitos nustatė identišką penkių pamatinių asmenybès bruožų rinkinị ${ }^{13}$. Jų pagrindu ir buvo sukurtas šiame tyrime panaudotas testas NEO-PI-R ${ }^{14}$.

Šis testas sulaukè visuotinio specialistų pripažinimo, atlikta keli tūkstančiai tyrimų, paaiškejo jo aukštas patikimumas, geros psichometrinès savybės ${ }^{15}$. Testas išverstas į 40 pasaulio kalbų. Jis taip pat išverstas ir adaptuotas Lietuvoje ${ }^{16}$.

Mūsų tyrimo tikslams pasiekti yra ypač svarbu, kad šiuo testu dažnai pavyksta nustatyti statistiškai reikšmingus ryšius tarp šia metodika įvertinamų pamatinių asmenybės bruožų ir žmonių elgesio įvairiose gyvenimo srityse ${ }^{17}$. Tuo remiantis ir buvo kelta prielaida, kad tai pavyks ir tiriant gydytojų elgesi, t. y. bus rasti statistiškai reikšmingi ryšiai tarp pamatinių gydytojų asmenybės bruožų ir jų gynybinių reakcijų gydymo procese.

Apibūdinsime kiekvieną iš NEO-PI-R tiriamų pamatinių asmenybės bruožų.

Neurotizmas. Šis bruožas apibūdina žmogaus emocinio stabilumo ir prisitaikymo laipsni. Jis rodo, kiek asmuo atsparus stresui, ịtampai, ịvairaus pobūdžio spaudimui. Aukštu neurotizmu pasižymintys asmenys jautresni stresinèms situacijoms, rečiau sugeba reaguoti ị jas konstruktyviai, jų reakcijoje dominuoja neigiami jausmai, tokie kaip baimé, liūdesys, nepasitenkinimas, pyktis ir pan.

Gydytojas savo veikloje neretai susiduria su stresinèmis situacijomis. Būtinybe priimti atsakingą sprendimą yra viena iš jų. Dèl to buvo iškelta hipotezè, kad aukštu neurotizmu pasižymintys gydytojai jautresni tokioms situacijo-

10 Atkinson, R. L.; Atkinson, R. C.; Smith, E. E.; Bem, D. J.; Nolen-Hoeksema, S. Hilgard's Introduction to Psychology (13 ed.). Orlando, Florida: Harcourt College Publishers, 2000, 6, p. 437.

11 Digman, J. M. Personality structure: Emergence of the five-factor model. Annual Review of Psychology. 1990, 41: 417-440.

12 Kaplan, R. M.; Saccuzzo, D. P. Psychological testing: Principles, applications, and issues (8th ed.). Belmont, CA: Wadsworth, 2013.

13 Digman, J. M., op cit.

14 Paul ,T.; Costa, R. R. McCrae Revised NEO Personality Inventory (NEO PI-R) and NEO Five-Factor Inventory (NEO-PI-R), 1992.

15 Barkauskiene, R.; Zukauskiene, R The Lithuanian version of the NEO PI-R: Preliminary findings on psychometric properties. 13th European Congress on Personality, Athens - Greece, July 22-26, 2006.

16 Žukauskienè, R.; Barkauskienè, R., supra note 8.

17 Irving, B.; Weiner, R. L. Greene Handbook of Personality Assessment. John Wiley and Sons, p. 2011. 
mis, dažniau sieks jų išvengti ir, atitinkamai, dažniau naudos gynybinès medicinos priemones.

Ekstraversija apibūdina tokios savybès kaip socialumas, komunikabilumas, visuomeniškumas, aktyvumas bei atkaklumas. Aukšta ekstraversija pasižymintys asmenys noriai ir aktyviai bendrauja su kitais, pasižymi santykių įvairove ir intensyvumu, rodo aukštą aktyvumo lygị, išorinių paskatų poreikį. Ekstravertiškas asmuo noriai susipažįsta ir bendrauja su kitais, jam būdinga didelè kitų žmonių tolerancija, aktyvi socialinė integracija.

Galima daryti prielaidą, kad gydytojai, pasižymintys aukštesne ekstraversija, aktyviai ir lengvai bendraujantys ir greitai randantys bendrą kalbą su aplinkiniais, geriau nei intravertai randa savitarpio supratimą su nepatenkintais pacientais ir kitais asmenimis, kurie galètų kelti pretenzijas gydytojui. Tai, savo ruožtu, turètų mažinti gydytojų nerimą, siekimą vengti atsakingų sprendimų ir polinki taikyti gynybinès medicinos priemones.

Atvirumas patyrimui. Šiuolaikinis žmogus „atakuojamas“ didžiulių informacijos srautų. Nauja patirtis, žinios, ịspūdžiai ir pan. pasiekia jị darbe, šeimoje, per daugybę visuomenès informavimo priemonių, nepaliaujamai keldama grèsmes jo vidiniam stabilumui, versdama visą laiką intensyviai keistis. Žmonès skiriasi pagal tai, kaip jie reaguoja ì naują informaciją. Nemaža žmonių dalis ginasi nuo jos, tuo tarpu kiti - atviri jai. Atvirumu patyrimui pasižymintiems asmenims būdingas žingeidumas, smalsumas, laki vaizduotè, dèmesys, įvairiausių žinių troškimas, domėjimasis savo ir kitų žmonių vidiniu pasauliu.

Galima kelti hipotezę, kad gydytojai, kurie atviri naujai patirčiai, mažiau bijo naujoviškų, net ir rizikingų sprendimų. Jiems būdingas atvirumas naujoms žinioms leidžia sukaupti žinias, kurios leidžia sẻkmingiau priimti tinkamus sprendimus atsakingose ir rizikingose situacijose. Dèl to jie turètų mažiau bijoti tokių sprendimų ir jausti mažesnị poreikị naudoti gynybos medicinos priemones.

Sutariamumas. Šis bruožas apima tokias žmogaus charakteristikas kaip draugiškumas, nuoširdumas, geranoriškumas, altruistiškumas, empatija, siekimas padèti kitiems. Galima kelti hipotezę, kad sutariamumu pasižymintys gydytojai jaučia didesni poreiki padèti pacientui. Šis poreikis turètų padèti jiems geriau įveikti su atsakingu sprendimu siejamus nuogąstavimus dèl savo paties saugumo ir galimų nemalonumų.

Sąmoningumas. Šis bruožas apima poreikị gerai suplanuoti viską, ką asmuo daro, siekimą numatyti kiekvieno veiksmo galimas pasekmes, kelti tikslus ir kryptingai jų siekti. Šiems asmenims būdinga savivalda, drausmingumas, atsakingumas, tikslumas ir kruopštumas. Tuo tarpu žemą sąmoningumo lygi turintys žmonės yra išsiblaškę, neorganizuoti, mažiau paisantys taisyklių, linkę veikti vien emocijų vedami.

Galima kelti hipotezę, kad aukštu sąmoningumu pasižymintys gydytojai, susidūrę su būtinybe priimti atsakingą ir rizikingą sprendimą, bus mažiau linkę 
pasiduoti su didesne atsakomybe siejamam nerimui, mažiau sieks išvengti sprendimo.

Taigi, atsižvelgiant ì pamatinių asmenybės bruožų apibūdinimus logiška tikètis, kad jie bus susiję su gynybinių reakcijų formavimusi gydytojo veikloje. Apibendrinant galima kelti prielaidas ir dèl atskirų asmenybės dimensijų ryšio su polinkiu naudoti gynybinès medicinos priemones pobūdžio: tik neurotiškumas turètų teigiamai koreliuoti su polinkiu naudoti gynybinès medicinos priemones; kuo aukštesni ekstraversijos, sutariamumo, sąmoningumo, atvirumo patyrimui rodikliai, tuo mažiau turètų būti išreikštas gydytojo polinkis naudoti gynybinès medicinos priemones.

\subsection{Gydytojo polinkio naudoti gynybinès medicinos priemones ivertinimo metodika}

Gydytojo polinkiui naudoti gynybinès medicinos priemones tirti buvo naudojama Gynybinès medicinos taikymo anketa (GMTA), kurią parengè ir reprezentatyvią 2440 Lietuvos gydytojų imti ištyrė V. Justickis ir L. Labanauskas (2011).

GMTA pagrindą sudaro klausimai gydytojui apie penkis svarbiausius gynybinès medicinos pasireiškimo atvejus: a) „rizikingų“ pacientų vengimas, b) rizikingų procedūrų vengimas, c) nereikalingi siuntimai pas kitus specialistus, d) nereikalingų papildomų tyrimų skyrimas, e) nereikalingų vaistų išrašymas. Gydytojas prašomas įvertinti, kaip dažnai jis panaudoja kiekvieną iš išvardintų priemonių keliose skirtingose situacijose: 1) apskritai savo darbe; 2) po to, kai buvo liudininkas, kaip nuo kaltinimų dèl neteisingo gydymo gynėsi kitas gydytojas; 3) po to, kai nuo tokio pat kaltinimo gynèsi jis pats; 4) situacijose, kuriose, pasak tyrèjų, gydytojai ypač dažnai naudoja gynybos priemones - laiko trūkumas, sudètingas atvejis, pacientas - ịtakingas asmuo, pacientas leidžia suprasti, kad gerai išmano įstatymus, pernelyg reiklus, pasižymi konfliktiniu charakteriu, abejoja kiekvienu gydytojo veiksmu, nevertina savo sveikatos, yra prastos nuotaikos.

\subsection{Tiriamųjų atranka}

Tyrime dalyvavo 101 Kauno miesto gydytojas. Toks apklaustųjų skaičius užtikrina statistiškai patikimų koreliacijų nustatymą, kurių dydis nèra mažesnis nei 0,17 (esant patikimumo lygiui ne žemesniam kaip 0,05).

Pasirenkant atrankos metodus ir organizuojant tiriamųjų atranką, buvo siekiama užtikrinti galimybę palyginti šio tyrimo rezultatus su anksčiau minètu reprezentatyviu 2440 Lietuvos gydytojų tyrimu, kuriame buvo išbandytas GMTA tinkamumas. Tam buvo pasirinktas tikslinès atrankos metodas, formuojant tiriamųjų imtị taip, kad (kaip ir minètame tyrime) būtų atstovaujami visų dažniausių specializacijų gydytojai. Tiriamųjų grupę sudarẻ vidaus ligų gydyto- 
jai - 23, 8 proc., vaikų gydytojai - 2,0 proc., ausų, nosies, gerklès ligų gydytojai 10,9 proc., gydytojai akušeriai-ginekologai - 13,9 proc., gydytojai kardiologai 3.0 proc., chirurgai $-21,8$ proc., gydytojai anesteziologai-reanimatologai $-22,8$ proc., neurochirurgai - 1,0 proc., urologai - 1,0 proc.

Tačiau toks platus įvairių specialybių reprezentavimas pats savaime dar neužtikrina minètų tyrimų palyginamumo. 2440 gydytojų apklausa parodė, kad tarp kiekvienos specialybės gydytojų stebimi dideli polinkio naudoti gynybinès medicinos priemones skirtumai, todèl nemaža jų atsakymų variacijos dalis turètų būti paaiškinta kitais nei specialybè veiksniais ${ }^{18}$.

Kita vertus, gydytojų polinkis naudoti gynybinès medicinos priemones viename ir kitame tyrime buvo tirtas taikant tą pačią metodiką - tiriamiesiems atsakant ị tuos pačius klausimus. Todèl vieno ir kito tyrimo atsakymų i tuos pačius klausimus panašumas yra patogus kriterijus ịvertinti, kiek panašūs yra vieno ir kito tyrimo tiriamieji (t. y. ar abi atrankos kilo iš tos pačios populiacijos) ${ }^{19}$.

Panašumas tarp 2440 gydytojų ir mūsų apklaustų gydytojų atsakymų buvo juvertintas apskaičiuojant Pirsono linijinès koreliacijos tarp vienos ir kitos grupès atsakymų i tuos pačius klausimus vidurkių. Naudodami šį koeficientą, galèjome nustatyti panašumo tarp abiejų tyrimų vidurkių laipsnị, pavyzdžiui, jei atsakymų $\mathfrak{j}$ tam tikrą klausimą vidurkis yra aukštas viename tyrime, tai aukštas yra ir kitame, ir atvirkščiai ${ }^{20}$. Paaiškejjo, kad koreliacijos koeficiento dydis sudaré $0,784^{21}$. Tai labai glaudus ryšys, kuris yra statistiškai reikšmingas net 0,0001 lygiu. Linijinès koreliacijos koeficiento apskaičiavimas leido įvertinti šio koreliacinio ryšio determinacijos koeficientą, kuris pasirodè lygus 0,615. Tai reiškia, kad kiekvieną iš šių tyrimų galima naudoti prognozuojant kito rezultatus ${ }^{22}$.

Iš to darytina išvada, kad Kauno gydytojų tyrimo duomenys gali būti palyginami su reprezentatyviu visai Lietuvai 2440 gydytojų tyrimu ir pasitelkti šio tyrimo rezultatams aiškinti.

\section{Tyrimo rezultatai}

Kaip minèta, pagrindinis tyrimo tikslas buvo ịvertinti ryšį tarp pamatinių asmenybės savybių ir gydytojų polinkio naudoti gynybinès medicinos priemones.

Bendram polinkiui išaiškinti buvo atlikta tiriamųjų atsakymų, kiek jie naudoja gynybinès medicinos priemones, faktorinè analizè.

8 Labanauskas, L.; Justickis, V.; Sivakovaite, A., supra note 4, 134-147.

19 Thompson, S.; Sampling. John Wiley and Sons, 2012, p. 322-323.

20 Garson, G. Correlation. Statistical Associates "Blue Book" Series Book 3), 2012.

${ }_{21}$ Šis ir visi kiti statistiniai skaičiavimai buvo atlikti panaudojant statistinių programų paketą PASW Statistics18.

22 Čekanavičius, V. Taikomoji regresinè analizè socialiniuose tyrimuose, 2010 [interaktyvus]. [žiūrèta 2014-05-15]. <http://www.lidata.eu/index.php?file=files/mokymai/trast/trast.html\&course_file= trast_2_1_4.html>. 
Faktorinè analizè - tai matematinès statistikos metodas, kuris leidžia nustatyti tiesiogiai nestebimą (paslèptą, latentinị) veiksnị, kuris statistiškai susietas (koreliuoja) su keliais stebimais ir lemiantis koreliacijų tarp šių stebimų didị $\mathfrak{i}^{23}$. Buvo siekiama: a) nustatyti, ar ịvairios gynybinès medicinos apraiškos gydytojo veikloje turi bendrą pagrindą, tai yra ar egzistuoja hipotetinis bendrasis gynybinès medicinos priemonių panaudojimo polinkis (bendrojo gynybiškumo veiksnys), su kuriuo susiję ịvairiausios gynybinès medicinos apraiškos; b) jeigu taip, tai kokie yra šio veiksnio ryšiai su nurodytais pamatiniais asmenybès bruožai.

Faktorinè analizė buvo atlikta taikant pagrindinès komponentès metodą su tolesniu nustatytų veiksnių regresinių balų kiekvienam tiriamajam apskaičiavimu.

Faktorinės analizès rezultatai patvirtina, kad egzistuoja aiškus, apie 40 proc. $(38,988$ proc.) variacijos paaiškinantis veiksnys, kuris aiškiai dominuoja šių tiriamų atsakymų faktorinẻje struktūroje (žr. 1 paveikslą).

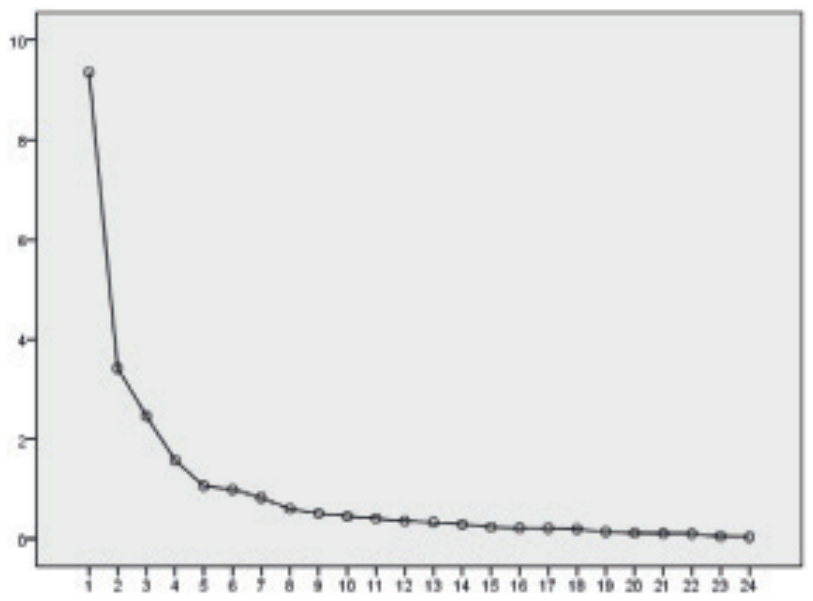

1 pav. Gydytojų atsakymų apie gynybinès medicinos priemonių panaudojimą faktorinè struktūra

Kaip matyti iš 1 paveikslo, išryškejjo pagrindinis veiksnys, kuris paaiškina ženklią bendrosios variacijos dalị. Akivaizdu, kad toks veiksnys yra tik vienas, kadangi visi kiti, pradedant antruoju, paaiškina tik labai mažą variacijos dalị. Išaiškinto veiksnio koreliacijos su atskiromis gynybinès medicinos apraiškomis nepalieka abejonių dẻ jo interpretacijos - tai yra bendrojo polinkio naudoti gynybinès medicinos priemones veiksnys. Tai patvirtina ir aukštos šio veiksnio koreliacijos su visais gynybinès medicinos apraiškų atvejais (žr. 1 lentelę).

23 Garson, G. D. Factor Analysis, Statnotes: Topics in Multivariate Analysis [interaktyvus]. [žiūrèta 2011-12-31] . <http://www2.chass.ncsu.edu/garson/pa765/statnote.htm >. 
1 lentelè. Faktoriaus „Bendrasis polinkis naudoti gynybines medicinos priemones“ ryšiai su atskiromis gynybinès medicinos apraiškomis

\begin{tabular}{|c|c|}
\hline Gydytojų atsakymai & $\begin{array}{l}\text { Koreliacijos su } \\
\text { nustatytu veiksniu } \\
\text { „Bendrasis polinkis } \\
\text { naudoti gynybos } \\
\text { medicinos priemo- } \\
\text { nes“ koeficientai }\end{array}$ \\
\hline $\begin{array}{l}\text { Kiek dažnai mintis, kad pacientas gali skųstis, skatino Jus elgtis } \\
\text { taip: Vengti „rizikingų“ pacientų (pvz., linkusių skųstis) }\end{array}$ & 0,558 \\
\hline $\begin{array}{l}\text { Kiek dažnai mintis, kad pacientas gali skųstis, skatino Jus elgtis } \\
\text { taip: Vengti atlikti reikalingas, bet „rizikingas“ procedūras }\end{array}$ & 0,606 \\
\hline $\begin{array}{l}\text { Kiek dažnai mintis, kad pacientas gali skųstis, skatino Jus elgtis } \\
\text { taip: Siųsti pacientą pas kitus specialistus, nors puikiai žinote, } \\
\text { kad to tikrai nereikia }\end{array}$ & 0,385 \\
\hline $\begin{array}{l}\text { Kiek dažnai mintis, kad pacientas gali skųstis, skatino Jus elgtis } \\
\text { taip: Skirti jam nereikalingus papildomus tyrimus }\end{array}$ & 0,592 \\
\hline $\begin{array}{l}\text { Kiek dažnai mintis, kad pacientas gali skųstis, skatino Jus elgtis } \\
\text { taip: Išrašyti daugiau vaistų, negu iš tikrųjų reikia }\end{array}$ & 0,668 \\
\hline $\begin{array}{l}\text { Prisiminkite atveji, kai kitam gydytojui teko gintis nuo paciento } \\
\text { kaltinimų. Ar po to atvejo pradejote dažniau taikyti „apsisaugo- } \\
\text { jimo“ priemones, pvz.: Vengti „rizikingų“ pacientų (pvz., linku- } \\
\text { sių skųstis) }\end{array}$ & 0,682 \\
\hline $\begin{array}{l}\text { Ar po to atvejo pradejote dažniau taikyti „apsisaugojimo“ prie- } \\
\text { mones: Vengti atlikti reikalingas, bet „rizikingas" procedūras }\end{array}$ & 0,554 \\
\hline $\begin{array}{l}\text { Ar po to atvejo pradejote dažniau taikyti „apsisaugojimo“ prie- } \\
\text { mones, pvz.: Siųsti pacientą pas kitus specialistus, nors puikiai } \\
\text { žinote, kad to tikrai nereikia }\end{array}$ & 0,545 \\
\hline $\begin{array}{l}\text { Ar po to atvejo pradejote dažniau taikyti „apsisaugojimo“ prie- } \\
\text { mones, pvz.: Skirti jam nereikalingus papildomus tyrimus }\end{array}$ & 0,661 \\
\hline $\begin{array}{l}\text { Ar po to atvejo pradejjote dažniau taikyti „apsisaugojimo“ prie- } \\
\text { mones: pvz.: Išrašyti daugiau vaistų, negu iš tikrųjų reikią }\end{array}$ & 0,678 \\
\hline $\begin{array}{l}\text { Ar po to atvejo pradejjote dažniau taikyti „apsisaugojimo“ prie- } \\
\text { mones, pvz.: Vengti „rizikingų“ pacientų (pvz., linkusių skųstis) }\end{array}$ & 0,633 \\
\hline $\begin{array}{l}\text { Ar po to atvejo pradejote dažniau taikyti „apsisaugojimo“ priemo- } \\
\text { nes, pvz.: Vengti atlikti reikalingas, bet „rizikingas“ procedūras }\end{array}$ & 0,611 \\
\hline $\begin{array}{l}\text { Ar po to atvejo pradejote dažniau taikyti „apsisaugojimo“ prie- } \\
\text { mones, pvz.: Siųsti pacientą pas kitus specialistus, nors puikiai } \\
\text { žinote, kad to tikrai nereikia }\end{array}$ & 0,504 \\
\hline
\end{tabular}




\begin{tabular}{|l|c|}
\hline $\begin{array}{l}\text { Ar po to atvejo pradejote dažniau taikyti „apsisaugojimo“ prie- } \\
\text { mones, pvz.: Skirti jam nereikalingus papildomus tyrimus }\end{array}$ & 0,689 \\
\hline $\begin{array}{l}\text { Ar po to atvejo pradejote dažniau taikyti „apsisaugojimo“ prie- } \\
\text { mones, pvz.: Išrašyti daugiau vaistų, negu iš tikrųjų reikia }\end{array}$ & 0,680 \\
\hline $\begin{array}{l}\text { Taikote šias priemones, kai: Neturite tiek laiko, kiek reikalauja } \\
\text { paciento būkle }\end{array}$ & 0,564 \\
\hline Taikote šias priemones, kai: Pernelyg sudètingas ir painus atvejis & 0,628 \\
\hline $\begin{array}{l}\text { Taikote šias priemones, kai: Pacientas yra ịtakingas, žinomas } \\
\text { asmuo }\end{array}$ & 0,592 \\
\hline $\begin{array}{l}\text { Taikote šias priemones, kai: Priemimo metu pacientas leidžia } \\
\text { Jums suprasti, kad gerai išmano ístatymus }\end{array}$ & 0,712 \\
\hline Taikote šias priemones, kai: Pacientas labai reiklus & 0,700 \\
\hline Taikote šias priemones, kai: Konfliktinis paciento charakteris & 0,712 \\
\hline $\begin{array}{l}\text { Taikote šias priemones, kai: Pacientas abejoja kiekvienu Jūsų } \\
\text { veiksmu ir sprendimu }\end{array}$ & 0,649 \\
\hline $\begin{array}{l}\text { Taikote šias priemones, kai: Pacientas pats nelabai vertina savo } \\
\text { sveikatą }\end{array}$ & 0,632 \\
\hline $\begin{array}{l}\text { Taikote šias priemones, kai: Pacientas aiškiausiai blogos nuotai- } \\
\text { kos }\end{array}$ & 0,646 \\
\hline
\end{tabular}

Taigi, faktorinès analizès rezultatai patvirtino, kad egzistuoja paslèptas faktorius „Bendras gydytojo polinkis naudoti gynybinès medicinos priemones“, kuris pasireiškia visuose gydytojų atsakymuose apie ịvairiausių priemonių panaudojimą skirtingose situacijose. Šio faktoriaus nustatymas yra labai svarbus. Tai, kad jis pasireiškia ịvairiausiose situacijose ir naudojant ịvairiausias priemones, reiškia, kad jis yra nepriklausomas nuo konkrečios situacijos, o yra glaudžiai susijęs su gydytojo asmenybe.

Šio veiksnio išryškejjimas dar labiau sustiprina ir pagrindžia motyvaciją atskleisti ryšius tarp gydytojo polinkio naudoti gynybinès medicinos priemones ir pamatinių jo asmenybės bruožų.

Atliekant faktorinę analizę buvo nustatyta kiekvieno gydy tojo atsakymų regresinè reikšmé pagal ši bendrąji veiksnị, tai yra apskaičiuota, kiek kiekvienam gydytojui būdingas šis bendras polinkis naudoti gynybines medicinos priemones. Toliau buvo apskaičiuotos šio bendrojo polinkio naudoti gynybines medicinos priemones koreliacijos su NEO-PI-R įvertintais asmenybės bruožais (žr. 2 lentelę). 
2 lentelè. Gydytojo polinkio naudoti gynybinès medicinos priemones ryšiai su NEO-PI-R asmenybès bruožais

\begin{tabular}{|l|c|}
\hline \multicolumn{1}{|c|}{ Asmenybės bruožai } & Koreliacijos koeficientai \\
\hline Neurotiškumas T & $0,168^{* *}$ \\
\hline Ekstravertiškumas T & $-0,062$ \\
\hline Atvirumas patyrimui T & 0,040 \\
\hline Sutarumas T & $-0,018$ \\
\hline Sąmoningumas T & 0,068 \\
\hline
\end{tabular}

2 lenteleje pateikti rezultatai parodo labai įdomią ryšio tarp gydytojo asmenybės pamatinių bruožų ir jo polinkio naudoti gynybinès medicinos priemones struktūrą. Apibūdindami NEO-PI-R skales ir keldami hipotezes dèl kiekvienos iš jų ryšio su gydytojo polinkiu naudoti gynybinès medicinos priemones, darème prielaidą, kad toks ryšys turètų būti nustatytas kiekvienai NEO-PI-R skalei.

Buvo tikètasi daugiafaktorinio ryšio tarp gydytojo asmenybės ir jo polinkio naudoti gynybinès medicinos priemones.

Tuo tarpu tyrimo rezultatai atskleide visiškai kitą vaizdą. Tikras ryšys tarp gydytojo asmenybės ir jo polinkio naudoti gynybinès medicinos priemones yra monofaktorinis. Yra tik vienas pamatinis asmenybės bruožas, kuris sieja gydytojo asmenybę su minètu polinkiu - neurotiškumas. Kartu šis ryšys yra glaudus ir statistiškai patikimas. Visi kiti NEO-PI-R bruožų koreliaciniai ryšiai yra silpni ir statistiškai nereikšmingi.

3 lentelès duomenys leidžia smulkiau išnagrinèti neurotiškumo sąsajas su ¡vvairiomis gynybinès medicinos apraiškomis. Joje pateikiami visi tie gynybinio elgesio atvejai, kurie statistiškai reikšmingai susiję su neurotiškumu.

3 lentelè. Gydytojo polinkio naudoti gynybinès medicinos priemones ryšiai su jo neurotizmu

\begin{tabular}{|c|l|c|}
\hline $\begin{array}{c}\text { Eil. } \\
\text { Nr. }\end{array}$ & \multicolumn{1}{|c|}{ Gynybinès medicinos apraiškos } & $\begin{array}{c}\text { Koreliacijos } \\
\text { koeficientai }\end{array}$ \\
\hline 1. & $\begin{array}{l}\text { Kiek dažnai mintis, kad pacientas gali skųstis, skatino Jus elgtis } \\
\text { taip: Vengti „rizikingų“ pacientų (pvz., linkusių skųstis) }\end{array}$ & $0,144^{*}$ \\
\hline 2. & $\begin{array}{l}\text { Kiek dažnai mintis, kad pacientas gali skųstis, skatino Jus elgtis } \\
\text { taip: Siųsti pacientą pas kitus specialistus, nors puikiai žinote, kad } \\
\text { to tikrai nereikia }\end{array}$ & $0,148^{*}$ \\
\hline 3. & $\begin{array}{l}\text { Kiek dažnai mintis, kad pacientas gali skųstis, skatino Jus elgtis } \\
\text { taip: Skirti jam nereikalingus papildomus tyrimus }\end{array}$ & $0,151^{*}$ \\
\hline
\end{tabular}




\begin{tabular}{|c|c|c|}
\hline 4. & $\begin{array}{l}\text { Kiek dažnai mintis, kad pacientas gali skųstis, skatino Jus elgtis } \\
\text { taip: Išrašyti daugiau vaistų, negu iš tikrųjų reikia }\end{array}$ & $0,199^{* *}$ \\
\hline 5. & $\begin{array}{l}\text { Ar po kito gydytojo kaltinimo atvejo, kuris padarè gydytojui di- } \\
\text { džiausią ịspūdį, jis pradejo dažniau vengti „rizikingų“ pacientų } \\
\text { (pvz., linkusių skųstis) }\end{array}$ & $0.217^{\star *}$ \\
\hline 6. & $\begin{array}{l}\text { Ar po kito gydytojo kaltinimo atvejo, kuris padare gydytojui di- } \\
\text { džiausią ìspūdị, jis pradejo dažniau vengti atlikti reikalingas, bet } \\
\text { „rizikingas“ procedūras }\end{array}$ & $0.171^{\star}$ \\
\hline 7. & $\begin{array}{l}\text { Ar po kito gydytojo kaltinimo atvejo, kuris padarè gydytojui } \\
\text { didžiausią isspūdi, jis pradejo dažniau siųsti pacientą pas kitus } \\
\text { specialistus, nors puikiai žino, kad to tikrai nereikia }\end{array}$ & $0.263^{* *}$ \\
\hline 8. & $\begin{array}{l}\text { Ar po kito gydytojo kaltinimo atvejo, kuris padare gydytojui di- } \\
\text { džiausią ispūdi, jis pradèjo dažniau skirti pacientui nereikalingus } \\
\text { papildomus tyrimus }\end{array}$ & $0.270^{* *}$ \\
\hline 9. & $\begin{array}{l}\text { Ar po to atvejo pradejote išrašyti daugiau vaistų, negu iš tikrųjų } \\
\text { reikia }\end{array}$ & $0.223^{* *}$ \\
\hline 10. & $\begin{array}{l}\text { Po atvejo, kai gydytojui pačiam teko gintis nuo kaltinimų, jis pra- } \\
\text { dejo dažniau vengti „rizikingų“ pacientų (pvz., linkusių skųstis) }\end{array}$ & $0,277^{\star *}$ \\
\hline 11. & $\begin{array}{l}\text { Po atvejo, kai gydytojui pačiam teko gintis nuo kaltinimų, jis } \\
\text { pradèjo dažniau vengti atlikti reikalingas, bet „rizikingas“ pro- } \\
\text { cedūras }\end{array}$ & $0,184^{* *}$ \\
\hline 12. & $\begin{array}{l}\text { Po atvejo, kai gydytojui pačiam teko gintis nuo kaltinimų, jis pra- } \\
\text { dèjo dažniau siųsti pacientą pas kitus specialistus, nors puikiai } \\
\text { žinojo, kad to tikrai nereikia }\end{array}$ & $0.194^{\star *}$ \\
\hline 13. & $\begin{array}{l}\text { Po atvejo, kai gydytojui pačiam teko gintis nuo kaltinimų, jis pra- } \\
\text { dejo dažniau skirti pacientui nereikalingus papildomus tyrimus }\end{array}$ & $0.156^{\star}$ \\
\hline 14. & $\begin{array}{l}\text { Po atvejo, kai gydytojui pačiam teko gintis nuo kaltinimų, jis pra- } \\
\text { dejo išrašyti daugiau vaistų, negu iš tikrųjų reikia }\end{array}$ & $0.177^{\star}$ \\
\hline
\end{tabular}

Taigi, gydytojo neurotizmas ne tik yra susijęs su bendruoju polinkiu naudoti gynybinès medicinos priemones. Neurotizmas pasižymi daugybe koreliaciniu ryšių su ịvairiausiomis gydytojo gynybinėmis reakcijomis. Darytina išvada, kad nustatytas ne tik statistiškai reikšmingas, bet ir daugiašalis ryšys tarp šių reiškinių.

\section{Rezultatų aptarimas}

Atlikto tyrimo rezultatai atskleidžia tikrai įdomų faktą: egzistuoja glaudus ryšys tarp gydytojo asmenybės ypatumų ir jo polinkio naudoti gynybinès medicinos priemones. Tyrimas patvirtino, kad tam tikri asmenybės bruožai padidina gydytojo jautrumą veiksniams, kurie skatina jị naudoti gynybinès medicinos priemones. 
Tačiau gera naujiena yra tai, kad šis ryšys yra monofaktorinio pobūdžio, t. y. gynybiškas elgesys statistiškai reikšmingai susijęs tik su vienu pamatiniu asmenybės bruožu - neurotiškumu.

Ši naujiena yra gera dèl to, kad iš esmès patikslina ir susiaurina problemą.

Jeigu, kaip buvo tikètasi, išryškètų visų pamatinių bruožų ryšys su polinkiu naudoti gynybinès medicinos priemones, tai reikštų, kad egzistuoja įvairios gynybinès medicinos veiksmams jautrios gydytojų grupès. Pavyzdžiui, jei pasitvirtintų prielaida, kad polinkis naudoti gynybines medicinos priemones yra glaudžiai susijęs su atvirumo patyrimui, sutariamumo, sąmoningumo ar ekstraversijos stoka, tai reikštų, kad reikia atskirų priemonių gydytojams, kurie pasižymi žemu atvirumu patyrimui, atskirų tiems, kurie pasižymi žemu sutariamumu ir pan. Tuo tarpu paaiškejjo, kad siekiant kontroliuoti nepageidaujamus gynybinès medicinos reiškinius dèmesio centre turi būti vienas gydytojų kontingentas - gydytojai, kurie pasižymi aukštu neurotiškumo lygiu.

Ryšys tarp gydytojo neurotiškumo ir jo polinkio naudoti gynybinės medicinos priemones gali būti sudètingas. Galima daryti prielaidą, kad padidintas neurotiškumas padidina gydytojų jautrumą pavojui, kuris susijęs su atsakingu sprendimu. Pagrindinis šio pavojaus šaltinis yra nepatenkintas pacientas - laukiama paciento reakcija ị gydymo nesėkmę. Šis pacientas nesèkmès atveju nepasitiki gydytojų paaiškinimais, atmeta paaiškinimą, kad gydymas buvo nesėkmingas nepaisant teisingo gydymo ir laikosi nuomonès, kad tikra priežastis buvo nepakankama gydytojo kompetencija, sąžiningumas ir pan. Ši problema nekyla, jei pacientas pasitiki gydytoju, jo kompetencija, sąžiningumu, nuoširdžiu noru padèti.

Taigi galima manyti, kad susijęs su atsakingu sprendimu pavojus yra tampriai susijęs su gydytojo numanomu paciento nepasitikejimu ir iš jo kylančiomis reakcijomis ił neigiamas atsakingo sprendimo pasekmes. Nėra abejonių, kad su šia problema susiduria kiekvienas gydytojas, tačiau gydytojas, pasižymintis aukštu neurotiškumu, turètų būti itin jautrus jai. Būtent jam atsakingas sprendimas ir su juo susijęs apkaltinimo pavojus sukelia daugiausiai nerimo ir siekimo išvengti su atsakingu sprendimu susijusio pavojaus ir nepatiklaus paciento reakcijos ị galimą gydymo nesèkmę. Tolesni tyrimai turètų pagilinti mūsų žinias dẻl ryšių tarp, iš vienos pusès, gydytojo sugebejimo nustatyti gerą kontaktą su pacientu, igyti jo pasitikejjimą ir, iš kitos, jo neurotiškumo.

Galima manyti, kad aukšto neurotiškumo gydytojui, jam priimant atsakingą sprendimą, susidaro savotiškas „užburtas ratas“. Iš vienos pusès, padidintas nerimas trukdo gydytojui nustatyti gerą psichologinị kontaktą su pacientu, suprasti ji, ígyti jo pasitikèjimą, iš kitos pusès, tas nepakankamas kontaktas tampa priežastimi, kuri verčia gydytoją nepasitiketi pacientu, bijoti jo ir vengti asmeniškai priimti atsakingus sprendimus jo atžvilgiu. 
Manytina, kad pagrindinis kelias šiam užburtam ratui sustabdyti yra padèti gydytojams (ypač padidinto neurotiškumo ir didesnio jautrumo pavojams, susijusiems su atsakingų sprendimų prièmimu) suprasti pacientą ir igyti jo pasitikejjimą.

Psichologine gydytojo bendravimo su pacientu pusė yra ne mažiau svarbi ir sudètinga, nei medicininè. Nekelia abejonių, kad gydytojas turi būti pasirengęs suvokti psichologines savo bendravimo su pacientu problemas tiek pat gerai, kaip ir biologines. Aišku ir tai, kad gydytojas turi būti tam specialiai rengiamas, jam turi būti suteiktos reikiamos žinios ir iggūdžiai, kaip tinkamai bendrauti su pacientu. Šių žinių ir igūdžių stoka neišvengiamai kelia gydytojui problemas bendraujant su pacientu, paskatina savitarpio nepasitikejjimą, baimę, konfliktiškumą. Toks gydytojas, susidūręs su būtinybe priimti atsakingą sprendimą, vietoje to, kad pagilintų savitarpio supratimą su pacientu ir padètų jam suprasti šio sprendimo būtinybę ir susijusias su juo rizikas, vengia šio sprendimo.

Svarbu pažymèti, kad nèra būtinybès ,išradinèti dviračio“ gerinant gydytojo psichologinị parengimą, jo sugebejimą suprasti pacientą ir bendrauti su juo. Medicinos mokslas seniai išvystė veiksmingas gydytojų psichologinio rengimo bendravimui su pacientu priemones. Viena iš ypač paplitusių yra Balinto grupès. Tai specialūs gydytojų susitikimai, kurie dažniausiai vyksta dalyvaujant profesionaliam psichologui, jų metu pristatomas medicininis atvejis ir gydytojai mokomi suvokti psichologines problemas, kurios kyla bendraujant su konkrečiu pacientu, gydytojui vykdant diagnostines ir gydymo priemones. Balinto grupés veikia 26 pasaulio šalyse ${ }^{24}$. Mokymasis Balinto grupeje ịtrauktas ị medicinos specialybės studentų rengimo universitetines programas Vokietijoje $e^{25}$. Dalyvavimo šiose grupèse veiksmingumas, gerinant gydytojo santykius su pacientu, vengiant konfliktų ir išplaukiančių nepageidaujamų ịvykių, ịtikinamai patvirtintas daugeliu tyrimų ${ }^{26},{ }^{27},{ }^{28},{ }^{29}$.

24 International Balint Federation 2014 [interaktyvus]. [žiūrèta 2014-05-15]. <http://www. balintinternational.com/membercountries.html $>$.

25 Heide, O. Introduction to Balintwork. On Balint groups - origins and present state. The International Balint Federation. July 2002 [interaktyvus]. [žiūrèta 2014-05-15]. <http://www. balintinternational.com/downloads/introbalint.pdf $>$.

26 Jing, W.; Otten, H.; Sullivan, L.; Lovell-Simons, L.; Granek-Catarivas, M.; Fritzsche, K. Improving the doctor-patient relationship in China: the role of balint groups. Int J Psychiatry Med. 2013, 46(4): 417-427.

27 Kjeldmand, D.; Holmströhm, I. Balint Groups as a Means to Increase Job Satisfaction and Prevent Burnout Among General Practitioners. Annals of Family Medicine [interaktyvus]. 2008, vol. 6, no. 2 [žiūrèta 2014-03-30]. <www.annfammed.org >.

28 Alan, H.; Johnson, Ph. D; Donald, E.; Nease, Jr. M. D; Laurel, C.; Milberg, Ph. D; Richard, B.; Addison, Ph. D. Essential Characteristics of Effective Balint Group Leadership Residency Education. 2004, vol. 36, no. 4: 253-257.

29 Chen, P. W. Healing the doctor-patient divide. New York Times [interaktyvus]. September 11, 2008 [žiūrèta 2014-05-15]. <http://www.nytimes.com/2008/09/11/health/chen9-11.html>. 
Balinto grupès, kaip ir kitos gydytojo psichologinio rengimo bendravimui su pacientu formos, kol kas nèra pakankamai diegiamos Lietuvoje. Minejjome, kad darbas su pacientu reikalauja iš gydytojo tiek medicinos, tiek psichologiniu kompetencijų. Neturintis pastarųjų gydytojas neišvengiamai „šlubuoja“ viena koja, turi sunkumų sprendžiant savitarpio supratimo ir pasitikejimo su pacientu problemas, kas sukelia tolesnes jų bendravimo problemas, tame tarpe ir gynybinès medicinos priemonių panaudojimą ${ }^{30}$.

Šių žinių ir iggūdžių stoka neišvengiamai kelia Lietuvos gydytojui problemas bendraujant su pacientu, padidina jo santykių su pacientu konfliktiškumą, skatina savitarpio nepasitikejimą, baimę. Gynybinès medicinos priemonių panaudojimas yra tik viena iš daugybès šios problemos pasekmių.

\section{Išvados}

1. Egzistuoja tamprus ryšys tarp gydytojo asmenybės ypatumų ir jo polinkio naudoti gynybinès medicinos priemones.

2. Šis ryšys yra monofaktorinio pobūdžio, ji sudaro tik vienas pamatinis asmenybės bruožas - neurotiškumas. Šis asmenybės bruožas susijęs tiek su bendruoju gydytojo polinkiu naudoti gynybinès medicinos priemones, tiek su atskirais gynybinès medicinos pasireiškimais gydytojo veikloje.

3. Padidintas neurotiškumas padidina gydytojų jautrumą pavojui, kuris susijęs su atsakingu sprendimu. Tas pavojus visų pirma susijęs su laukiama paciento reakcija ị gydymo nesèkmę.

4. Gydytojo nerimas dèl paciento reakcijos nesèkmingo gydymo atveju susijęs su problemomis, su kuriomis susiduria gydytojas, formuodamas savo santykius su pacientu ir igydamas jo pasitikejimą.

5. Lietuvoje stokojama gydytojų rengimo bendravimui su pacientu sistemos, Lietuva nepanaudoja didelès patirties, kuri šiuo atžvilgiu sukaupta užsienio šalyse.

\section{Literatūra}

1. Johnson, A., Donald, E., Nease, J., et al. Essential Characteristics of Effective Balint Group Leadership. Residency Education. 2004, vol. 36, no. 4, 253-257.

2. Atkinson, R. L.; Atkinson, R. C.; Smith, E. E.; Bem, D. J.; Nolen-Hoeksema, S. Hilgard's Introduction to Psychology (13 ed.). Orlando, Florida: Harcourt College Publishers: 2000, 437.

3. Barkauskiene, R.; Zukauskiene, $\mathrm{R}$ The Lithuanian version of the NEO PI-R: Preliminary findings on psychometric properties. 13th European Congress on Personality, Athens - Greece, July 22-26, 2006.

30 Lelorain, S.; Brédart, A.; Dolbeault, S.; Cano, A.; Bonnaud-Antignac, A.; Cousson-Gélie, F.; Sultan, S. How can we explain physician accuracy in assessing patient distress? A multilevel analysis in patients with advanced cancer. Patient Education and Counseling. 2014, 94(3): 322-327. 
4. Chen, P. W. Healing the doctor-patient divide. New York Times [interaktyvus]. September 11, 2008 [žiūrèta 2014-05-15]. <http://www.nytimes.com/2008/09/11/ health/chen9-11.html>.

5. Čekanavičius, V. Taikomoji regresinè analizè socialiniuose tyrimuose, 2010 [interaktyvus]. [žiūrèta 2014-05-15]. < http://www.lidata.eu/index.php?file=files/ mokymai/trast/trast.html\&course_file=trast_2_1_4.html $>$.

6. Digman, J. M. Personality structure: Emergence of the five-factor model. Annual Review of Psychology. 1990, 41: 417-440.

7. Heide, O. Introduction to Balintwork. On Balint groups - origins and present state. The International Balint Federation [interaktyvus]. July 2002 [žiūrèta 2014-0515]. <http://www.balintinternational.com/downloads/introbalint.pdf>.

8. International Balint Federation 2014 [interaktyvus]. [žiūrèta 2014-05-15]. < http:// www.balintinternational.com/membercountries.html >.

9. Irving, B.; Weiner, R. L. Greene Handbook of Personality Assessment. John Wiley and Sons, 2011.

10. Jing, W.; Otten H.; Sullivan, L.; Lovell-Simons. L.; Granek-Catarivas. M.; Fritzsche, K. Improving the doctor-patient relationship in China: the role of balint groups. Int J Psychiatry Med. 2013, 46(4): 417-427.

11. Kaplan, R. M.; Saccuzzo, D. P. Psychological Testing: Principles, Applications, and Issues (8th ed.). Belmont, CA: Wadsworth, 2013.

12. Kaplan, R.; Saccuzzo D. Psychological Testing: Principles, Applications, and Issues Dennis Cengage Learning, Psychology. 2008.

13. Kjeldmand, D.; Holmströhm, I. Balint Groups as a Means to Increase Job Satisfaction and Prevent Burnout Among General Practitioners. Annals of family medicine [interaktyvus]. 2008, vol. 6, no. 2 [žiūrèta 2014-05-15]. <www.annfammedorg>.

14. Labanauskas, L.; Justickis, V.; Sivakovaitè, A. Gynybinè medicina Lietuvos sveikatos apsaugoje: gydytojų gynybinių reakcijų formavimasis. Sveikatos politika ir valdymas. 2013, 1(5): 134-147.

15. Labanauskas, L.; Justickis, V.; Sivakovaitè, A. Istatymo įvykdomumas. Šiuolaikinè gydytojo atsakomybès didinimo tendencija. Socialiniu mokslu studijos. 2010, 4(8): 89-107.

16. Labanauskas L., Justickis V., Sivakovaitė A. Gynybinės medicinos reiškinių paplitimas Lietuvoje (Pagrindiniai 2440 Lietuvos gydytojų tyrimo rezultatai). Sveikatos politika ir valdymas. 2011, 1(3): 158-170.

17. Lelorain, S.; Brédart, A.; Dolbeault, S.; Cano, A.; Bonnaud-Antignac, A.; CoussonGélie, F.; Sultan, S. How can we explain physician accuracy in assessing patient distress? A multilevel analysis in patients with advanced cancer. Patient Education and Counseling. 2014, 94(3), 322-327.

18. Paškevičius, L. Kompleksinio požiūrio ị pacientų saugą ir rizikos valdymą sveikatos priežiūros organizacijose paieška. Sveikatos politika ir valdymas. 2014, 1(6): 133-156.

19. Paul, T.; Costa, R. R. McCrae Revised NEO Personality Inventory (NEO PI-R) and NEO Five-Factor Inventory (NEO-PI-R), 1992.

20. Thompson, S. Sampling. John Wiley and Sons, 2012, p. 322-323. 


\title{
Doctor's Personality and His Propensity to Use Defence Medicine
}

\author{
Viktoras Justickis, Rita Bandzevičienè, Laimutis Paškevičius \\ Mykolas Romeris University, Lithuania \\ Ina Bozokienè \\ Kaunas city hospital, Lithuania
}

Summary. Defensive medicine is a faulty phenomenon in the healthcare when a physician instead of doing his best to help his patient is concentrated on defending himself from any legal prosecution in the case on unsuccessful treatment. Empirical studies in Lithuania have demonstrated the prevalence and adverse consequences of this phenomenon in this country (Labanauskas and Justickis, 2011). These studies have discovered many factors promoting the spread of defensive medicine. Of special importance has been the discovery of broad differences among physicians in their ability to resist the effect of the factors promoting the defence medicine (Labanauskas and Justickis, 2013).

The aim of the current study is to investigate interconnections between doctor's susceptibility to factors promoting defence medicine and his personality.

101 physicians working at the Kaunas city hospital participated in the study. The research tools include NEO-PI-R test designed for the examination of the basic personality traits and inventory for the study of doctors' propensity to use the methods of the defence medicine (IUDM - Inventory for the study of the Use of Defensive Medicine).

A close link between doctor's personality and his propensity to use defensive medicine and the mono-factorial nature of this link was demonstrated. It was shown that the link connecting one's personality and the propensity to use defensive medicine is the doctor's neurotism.

This provided the opportunity to single out the part of physicians that are most vulnerable for factors promoting defensive medicine and who need psychological and other support resisting the effect of these factors. This provides a new opportunity for prevention of a multi-sided approach to prevention of adverse events that have been caused by doctors' propensity to defensive medicine (Paškevičius, 2014).

Keywords: doctor's personality, defensive medicine, adverse events, doctor's liability, Balint groups.

Viktoras Justickis, Mykolo Romerio universiteto Socialinès politikos fakulteto Psichologijos katedros profesorius. Mokslinių tyrimų kryptys: medicinos teisè, kriminologija, psichologija.

Viktoras Justickis, Mykolas Romeris University, Faculty of Social Policy, Department of Psychology, Professor. Research interests: medical law, criminology, psychology. 
Rita Bandzevičienè, Mykolo Romerio universiteto Socialinės politikos fakulteto Psichologijos katedros profesorè. Mokslinių tyrimų kryptys: stresas, penitencinè (korekcinè) psichologija, rizikos vertinimas, inovacijų psichologija.

Rita Bandzevičienè, Mykolas Romeris University, Faculty of Social Policy, Department of Psychology, Professor. Research interests: stress, penitentiary (correctional) psychology, risk assessment, innovation psychology.

Laimutis Paškevičius, Mykolo Romerio universiteto Politikos ir vadybos fakulteto Politikos mokslų instituto doktorantas. Mokslinių tyrimų kryptys: sveikatos priežiūros vadyba, sveikatos priežiūros kokybė, pacientų sauga, rizikos valdymas, vadyba, žmonių išteklių vadyba, strateginis valdymas, operatyvusis vadovavimas.

Laimutis Paškevičius, Mykolas Romeris University, Faculty of Policy and Management, Institute of Political Sciences, Doctoral student. Research interests: healthcare management, healthcare quality, patient safety, risk management, management, human resources management, strategic management, operational management.

Ina Bozokienė, Všt Respublikinė Kauno ligoninè. Mokslinių tyrimų kryptys: teisès, klinikinè psichologija.

Ina Bozokiene், Kaunas city hospital. Research interests: clinical and forensic psychology. 